\title{
The Human Genome Project as a case study in the debate about the relationship between theology and natural science ${ }^{*}$
}

\author{
Johan Buitendag \\ Department of Systematic Theology and Christian Ethics \\ University of Pretoria
}

\begin{abstract}
The author presents a review article on the book, Brave new world? Theology, ethics and the human genome, edited by Celia DeaneDrummond and published in 2003 by T\&T Clark International in London. After a rather elaborate exposition, he appraises the collection of essays in terms of the dialogue between theology and the natural sciences. As an acid test, he assesses the challenge Kant, however, dealt with, namely to combine and to separate the right things. Kant pushed this to extremes and ended up with both solipsism and dualism. This article tackles the challenge differently and concludes that theology is an a posteriori science and that by means of différance, knowledge of the noumenon is indeed possible. The author therefore appreciates the different contributions in the book in this light. Deane-Drummond's proposal that a virtue ethic should be complemented by certain biblical values is therefore viewed rather sceptically. This remains a transcendental enterprise where epistemology precedes ontology.
\end{abstract}

\section{OPTICS}

As point of departure for the exposition and analysis of the sensational collection of essays, Brave new world? Theology, ethics and the human genome, compiled by Celia Deane-Drummond and published at the end of 2003 by T \& T Clark International in London, I wish to tackle the issue of the

\footnotetext{
"Review Article: Deane-Drummond, C (ed) 2003. Brave new world? Theology, ethics and the human genome. London: T \& T Clark International.
} 


\section{The Human Genome Project as a case study}

familiar dialogue between theology and natural science. The editor professes in the foreword that she too, and pertinently, wishes to stimulate this dialogue (Deane-Drummond 2003:xxvi). However, as this debate brings widely divergent epistemologies and also the ontologies of different orders in dialogue with one another, I wish to employ as a horizon of understanding, two basic points of departure from Immanuel Kant's philosophy - two perspectives which in their extreme forms have admittedly been superseded (solipsism and dualism) but which nevertheless in a moderate form still give direction in the debate, even if it is by way of falsification.

It is probably not quite as generally known that Kant initially oriented himself specifically to the empiricism and philosophy of his time. Though the natural sciences first caught his attention the most, his philosophical deliberations emerged much later. In 1755, still in his pre-critical phase, Kant had already written his first book on judging the forces in nature and a theory about heaven. Also in that year, he handed in his thesis on the understanding of fire. His admiration for Isaac Newton is incontrovertibly clear in this thesis. What is important now for the purposes in question, however, are the following matters. On the one hand, Kant did try to indicate as such the matters he thought should be combined, and on the other hand, he tried to separate from one another the matters he thought could not be combined. I believe this combining but also separating of matters is what is really involved in the dialectic between theology and the natural sciences. But then it should be the right matters that are combined and also the right matters that are separated from one another! These particular bounds are all too easily exceeded by interlocuters. Either the matters which belong together are dealt with separately from one another, or matters which are essentially different are intermingled with one another. In this, therefore, lies the decisive test of successful dialectics.

The following brief orientation to Kant is necessary for the argument. In Kant's time, two main schools of thought dominated philosophy, namely English empiricism and continental rationalism. They are not only independent of each other, but are also often contrasted as though a choice had to be made between them. The rationalists could not do otherwise than make the thinking "l" the basis and foundation of everything. By contrast, the empiricists depended willy-nilly on the individual's sensory perception. But to Kant it was clear that both these views were one-sided. The correct concept of knowledge had to be a perfect unity between a priori (rational) thought and a posteriori (sensory) perception. Therefore all experience had to be placed specifically within the clinical rules of pure reason. Reason is therefore actively involved in 
placing the forms of appearance of space and time into particular categories of thought. Only then do the a priori synthetic judgements arise. This is knowledge prior to any experience and is simultaneously also necessarily and generally true. This does not mean that thought and observation can also be taken as dualistic. In the field of observation or experience of reality, Kant finds these a priori principles; whereas in the area of the will, he discovers the set of rules of moral conduct; and in the area of taste and feeling, he identifies aesthetic judgements of nature and art. The following quotation from Kant ([1948] 1972:53) reflects to some degree his argument about the mutual relationship:

\begin{abstract}
All rational knowledge is either material and concerned with some object, or formal and concerned solely with the form of understanding and reason themselves - with the universal rules of thinking as such without regard to differences in its objects. Formal philosophy is called logic; while material philosophy, which has to do with determinate objects and with the laws to which they are subject, is in turn divided into two, since the laws in question are laws either of nature or of freedom. The science of the first is called physics, that of the second ethics. The former is also called natural philosophy, the latter moral philosophy.
\end{abstract}

In today's post-modern world it is clear that Kant ([1934] 2000:15, 17) with his conviction of the "Copernican revolution" which places not the sun but mankind at the centre of the universe, has nevertheless actually become outdated. He cannot get away from a rationalistic solipsism, and idealism clearly dominates his thinking. It is still human beings with all their capacities who conceive of all reality. This means that Kant did not really succeed in combining the right matters. Reason and experience are after all still the obverse sides of the same coin, and in effect he did not succeed either in really combining subject and object. Of course, the error he made was in overvaluing human reason - as though reason is timeless and can furthermore also exist in the singular (Bryant \& Searle 2004:13). In this way he de-historicises reality and consequently this leads to a specific docetism. It is clear that Kant treated the geometry of Euclid and the absolute time and space of Newton as timeless givens, which was not really a priori thinking about facts, but merely camouflaged a posteriori observation (McGrath 2001:32; 2002:270; 2004:159). Stated differently, in his combining of matters he did not go far enough and still merely ended with matters solely of the 
subject (Idealism). After all, reality is far more than simply human reason and senses. ${ }^{1}$

The other important matter Kant taught us for the purposes of this argument, is that God cannot be a postulate of our reason. God exists per se and differs materially from the reality at hand. Kant also states categorically in his Critique of Pure Reason that the existence of God cannot be shown, not by way of ontological argument nor by way of cosmological proof (Kant [1934] 2000:402-427). Therefore the absolute can never be made the object of possible experience and consequently neither can it become positive knowledge at all. In fact, we deal with two realities, a noumenal and a phenomenal reality. Concerning the former, we can only know that it is there. Knowledge is therefore only possible in terms of specific forms of appearance such as those in which reality presents itself to me. Consequently, I can only know in the latter sphere alone, with its all-too-human co-ordinates of time and space. This basically means that we can only have knowledge about something on which we have as it were superimposed ourselves (Kant [1934] 2000:16). But let me give Kant's own definition of these two realities:

\begin{abstract}
At the same time, when we designate certain objects as appearances or sensible existences (phenomena), thus distinguishing our mode of intuiting them from their own nature as things in themselves, it is evident that by this very distinction we as it were place the latter, considered in this their own nature, although we do not so intuit them, in opposition to the former, or, on the other hand, we do so place other possible things, which are not objects of our senses, but are thought by the understanding alone, and call them intelligible existences (noumena).
\end{abstract}

(Kant [1934] 2000:211)

In the foreword to the second edition of the above-mentioned work, Kant ([1934] 2000:11-28) contrasts actual knowledge with feigned knowledge. We should realise that there is a ghastly gulf, or rather to use Lessing's expression, an "ugly ditch", between these two realities and that one would make an impermissible epistemological leap if one attempted to make pronouncements on absolute reality from the contingents. This tension is ever and always present (Kant [1934] 2000:17). In other words, knowledge of the absolute simply does not exist. Empirical science is therefore totally opposed to any form of a "metaphysical dogmatism" which would uncritically pretend to

\footnotetext{
${ }^{1}$ It is interesting to note that prof Jan Muis (2005:100) regards Kant's understanding of reality not as an anti-realistic constructionism, but rather as a "critical realism". I am not sure whether this is the case.
} 
have knowledge. It is precisely unbelief par excellence and therefore also contradictory to morality (Kant [1934] 2000:21).

Kant believes these two matters are ontologically separated from each other and cannot be mixed. But he takes this too far. He claims that no knowledge whatsoever is possible outside the world of forms of appearance. Taken to the absolute, this would naturally lead to dualism. For more about the present debate on the relationship between theology and natural science, see for example the criticism which people such as John Cobb $(1979: 49,10)$ and recently also Dingemans and Smelik (2005:146-148) levelled at Kant. In effect, it means that Kant separated different matters too radically from one another. Creation and Creator are in our opinion not really to be understood so independently of each other. There has to be an interface somewhere! But more about this in the concluding paragraph.

In spite of the above two points of criticism about Kant, which are important in the present discussion, I wish to add as an aside that Kant did in fact have a place for a type of inborn grace. The ens realissimum is, as stated, when man is stripped of all experience and historical trappings and only the moral meaning remains. This means that a person now intrinsically possesses a kind of archetype which makes him or her a rational, moral and personal being. Nor is this actual self invented, it is only discovered: "But just because we are not the authors of this idea, and because it has established itself in man without our comprehending how human nature could have been capable of receiving it, it is more appropriate to say that this archetype has come down to us from heaven and has assumed humanity" (Kant 1960:54). It is also all purely through grace. That is why grace is never opposed to nature, but is an intrinsic part of it. ${ }^{2}$

\section{COMPOSITION}

This book by Deane-Drummond has an interesting composition. One can clearly see that its composition is also intended to convey a message, similar to a typical prolegomenon of old. With its authentically human number, the six different sections of the book could be understood as concentric circles. Each section also consists of two chapters, like the steps of a ladder - a double helix perhaps? - which take the reader ever further. This places one inside an ever-larger framework, clearly designed to suggest that man cannot in any way be understood absolutely. The individual is therefore the point of intersection in a social, cultural, political, historical and theological matrix. With

\footnotetext{
${ }^{2}$ It would be an interesting enterprise to take this as the backdrop for the assessment of the "God spot" for example in the work of Newberg \& D'Aquili (2002)! This does not make God redundant, but gives us a special sense to be aware of the supernatural.
} 


\section{The Human Genome Project as a case study}

a little imagination, one can also see how the editor has arranged the material by starting with the situation at hand (current state of research) and then eventually placing it in the wider context of theology and ethics. She first follows a diachronic line when questioning specific historical trajectories and then a synchronic line, which in turn discounts the lateral dimensions of social, political and even liturgical contours. Certain ethical perspectives are interwoven throughout the arrangement, which attempt to indicate a course between the two kerbstones of the classical deontological and teleological methods of approach.

The Human Genome Project (HGP) has, in other words, posed a challenge to theology to establish a "genome morality" or even a "species ethics" (Habermas) inside a specific understanding of reality, which should serve as a broad framework for inter alia judging cloning. So the theological map also has to interpret the insights of natural science (Deane-Drummond 2003:xxii). The editor offers her personal contribution in a particular theory of virtue, which dates back to the ethics of Aristotle and of Aquinas, as a possible solution to an endeavour to find some direction from the divergent options. In a subsequent book (Deane-Drummond 2004) she builds further on this and then attempts to establish an alternative ethics in terms of a theory of virtue, which could combine a priori as well as a posteriori insights. This insight by Deane-Drummond is probably also one of the most important contributions of the book being discussed, and one suspects that the title, Brave new world?, might perhaps allude to the modest daring of a step in this direction as "playing God". This dialectic of subject and object is in fact what the critical knowledge of Kant is supposed to deal with. For this reason, I wish to conclude this review article with a proposal for a scientific theology, which would also take into account this interaction between subject and object in a wider horizon of understanding about the interface between theology and science. As implied above, the contributions in the book under discussion are also viewed eclectically from this optic.

The contributors to this book are all recognised researchers in different fields, ranging from chemical and biological scientists to famous theologians and ethicists. Most of the contributors are university lecturers in the United Kingdom. What is especially striking is the number of double doctorates they have - in theology as well as the natural sciences, of whom the editor is not least among them. Celia Deane-Drummond initially trained as a botanist and has a PhD in plant physiology as well as one in theology. She is currently the incumbent of the chairs of theology and biological sciences at the Chester College of Higher Education in England, and is also director of the recently founded Centre for Religion and the Biosciences at the same university. The 
origin of the book dates back to the editor's need, as long ago as 2001, to arrange a colloquium on the HGP and then to disseminate the information as widely as possible. This opportunity arose on March 2002. The eventual publication of the proceedings went further, however, than only the HGP, as is clearly evident in the previous paragraph.

\section{WHAT IS HUMANKIND?}

The HGP made a world-famous breakthrough in 2001 when it announced the first draft in the mapping of the human genome. The specific sequence of the four basic pairs of nucleotides in the human genome, namely adenine, thymine, cytosine and guanine, are therefore demarcated on the genome map. They represent a number of approximately 30 000-40 000 genes, moreover considerably fewer than had initially been thought. Of course, the first step in this achievement dates back as far as 1953 when James Watson and Francis Crick isolated the DNA molecule (deoxyribonucleic acid) and its self-replication. Many scientists later described the mapping of the approximately 3 billion DNA characters of the human genome as the single greatest human achievement ever, even greater than splitting the atom or landing the first man on the moon! (HGPI 2003). This achievement wrote the first chapter in the "Book of Life" on humankind. ${ }^{3}$

Deane-Drummond's premise for her undertaking was to regard genome mapping as the beginning of a long process in understanding humankind. After all, no scientist works in a vacuum. Therefore it can only be welcomed that Dr Watson at that time recommended to the State that $3 \%$ (later $5 \%$ ) of a massive $\$ 3000000000$ budget should be earmarked for research into the ethical, legal and social implications $\left(E L S I^{4}\right)$ of genome research. When one wishes to speak properly about man, this invariably involves a multidisciplinary undertaking. Consequently Deane-Drummond (2003:xxii) relies heavily on the insights of others, especially those of John Polkinghorne who acknowledged the epistemological difference between

\footnotetext{
${ }^{3}$ Francis Collins, director of the NHGRI of the USA's health department and Aristides Patrinos, head of the education department, won the "moon race" against Dr Graig J Venter of the private American company Celera Genomics. It is remarkable that the NHGRI completed the mapping first, since they followed a slower but more thorough process $(99,99 \%$ accurate) by building the genome map chromosome by chromosome. Celera Genomics initially indicated solely the elements of the map, and then assembled the fragments (Peters 2003a:145).

${ }^{4}$ Acronym for Ethical, Legal and Social Implications of the HGP.
} 
theology and science, but nevertheless understood them as complementing each other.

Without going in any way into the technical details of research on cloning, ${ }^{5}$ the following comment by John Bryant is important in the present work, namely that the issue of genetic diagnosis and manipulation before the ovum's implantation is, as far as he is concerned, unacceptable because “...full human status begins when a sperm fertilizes an egg" (DeaneDrummond 2003:15), also because “... pre-natal screening will be perceived as a form of eugenics" (Deane-Drummond 2003:17) and lastly also because "... it may be seen as a step too far in tampering with our own biological nature: the term 'playing God' is often used" (Deane-Drummond 2003:20). One also gains the impression that this is still an atomist view of human beings and that matters which should be combined are separated. Compare this also with Bryant's latest contribution in this regard (Bryant \& Searle 2004:53). One's total identity is not genetically determined. Being a person is after all a function of factors such as biology, culture and psychology - indeed, the book as a whole suggests this. For this reason I wish to cite Ruth Page's standpoint as confirmation: "There is a question whether early embryos, whose cells have not yet specialized, may be called life"6 (Deane-Drummond 2003:71). Peter Turnpenny is probably also closer to the mark when he points out that it is in fact the external environment that plays a role in switching genes on and off (Deane-Drummond 2003:31-32). Furthermore, researchers judge that genes always act cumulatively in a specific network (Deane-

\footnotetext{
${ }^{5}$ England's Human Genetics Advisory Commission was the first to distinguish between a reproductive and therapeutic cloning (see also Song 2002:26). The latter type of cloning uses mainly embryos to obtain stem cells. Such stem cells are also by their nature undifferentiated and have the potential to develop into any kind of bodily tissue and also therefore have immeasurable value for repairing and even replacing organs of the body. In particular, hereditary diseases such as Parkinson's, Alzheimer's, diabetes, heart and lung defects, etc could probably benefit from this in future. These stem cells also have to be extracted from the embryo within the first 4-6 days - a process which obviously kills the embryo. The surplus embryos from artificial insemination normally meet the need for embryonic stem cells. The latest research on adult stem cells indicates that when they are taken from certain parts of the adult, for example from the brain or spinal cord, they will probably also have the totipotential properties of embryonic stem cells (Deane-Drummond 2004:125). It even seems it might be possible to manipulate or even reprogramme such cells to make them differentiate in a particular selected direction (Aldhaus 2001:2). If cell differentiation can indeed be converted into a clean slate (dedifferentiation), the ethical issue of the ability to obtain and handle embryos (see also Peters 2003b:67) will of course become totally relative. Schüklenk (2002:785) refers in this regard to the leading Australian researcher into stem cells, Alan Trouson, who does think that it is just a question of time when adult stem cells can be cultivated without embryos. Messer (2001:7) confirms this too.
}

${ }^{6}$ By "life" she probably means a "human person". 
Drummond 2003:119). This gives recognition to matters which belong together.

For this reason, it is also good that, when referring to human beings, the larger horizon of life and death is discussed in the book. The emphasis ought not to be on life at all costs (Schweitzer), but rather on the quality of life, or as Heidegger understood this, on authentic life. Reiss also points out that although the average age of the population has risen significantly in recent decades in First-World countries, life expectancy has not increased to nearly the same proportion (Deane-Drummond 2003:51). In any event, extended life and unusually advanced age still remain undesirable. He relies too on the insights of for example Hannah Arendt who points out the ancient Greeks' conviction that a person's true essence is only completed in death. This accords with the insights of eco-theologians that death is incontrovertibly part of life. It is also to be welcomed that we hear that terminal patients should always be able to exercise choices, such as "nursing care only" or "do not resuscitate" (Deane-Drummond 2003:55). The famous Jeremy Taylor (1901:174) recognised this holistic truth as long ago as 1651: "Hither is to be reduced, that we be not too confident of the physician, or drain our hopes of recovery from the fountain through so imperfect channels; laying the wells of God dry, and digging to ourselves broken cisterns."

Messer (cited in Deane-Drummond 2003:103-107) avers that the human genome project poses real questions about health, disease and suffering. He relies heavily on Paul's "thorn in the flesh" (2 Cor 12) which Paul himself interpreted as the messenger of Satan, stating that he found peace of mind only in God's mercy. Based on Karl Barth's view of true freedom (CD III/4), Messer consequently also indicates that the medical model of disease and health is completely inadequate, precisely because it attempts to be neutral and value-free. Our right relationship with God, people and structures is first to offer us true health and moreover allows us to understand our life as eternal life. Mystery and paradox colour our understanding of reality. Health is therefore not a goal in itself, but the shalom of restored relationships. ${ }^{7}$ That is why we should be cautious when natural scientists think they see shalom in purely physiological terms (physicalist reductionism). Junker-Kenny's view of man as a "self-interpreting animal" therefore also refutes the traditional view that disease is merely a biological dysfunctionality (Deane-Drummond 2003:127). This also means that the definition the World Health Organization (WHO) gives of health, is basically unusable: "Health is a state of complete physical, mental and social well-being and not merely the absence of disease and infirmity." The definition is too narrow for the total wellness of humans and

${ }^{7}$ See for this also Hefner 2002: http://www.zygoncenter.org/zygonside.html 
too wide for basic health (Deane-Drummond 2003:100). An understanding of disease and health should preferably be placed in the horizon of a community which defines them. This is where the essence of being a human belongs. Moreover, human beings are also and always homines coram Deo. Indeed, the imago Dei should not be understood merely ontologically as a characteristic of being a human (cf Kant's archetype), but should be understood relationally as man's ability to react to God's voice and to live due to his grace. This places human beings in a network of relationships. Therefore, according to the Church of Scotland, the person who originates from cloning would also be fully an image of God (Deane-Drummond 2003:76). This is indeed a postulate to concur with.

\section{HISTORICAL TRAJECTORY AND LATERAL ORIENTATION}

Ian Barbour (2000) in his rather classical work about the relationship between theology and natural sciences refers to matters such as the danger of integration. He believes this would mean the end of theology. Matters are combined here and consequently they can no longer be distinguished. The book under discussion justifiably adopts a stance opposing this. In the spirit of Nietzsche's man who killed God and is being destroyed himself now, Szerszynski states also that the HGP did indeed map the human genome, but equally runs the risk of destroying humankind in the very same process (Deane-Drummond 2003:155)! The HGP may therefore degenerate into a totalitarian system which, as mathesis universalis would kill God, man and nature. Like the periodic table in chemistry, human beings are now absolutely embedded in a static blueprint of determinism. In this view, below the visible surface of observation all life is therefore genetically predisposed. This is immanentism in the full sense of the word. The actual point boils down to the fact that a 17th-century epistemology is followed, which interacts positivistically with reality. Homogeneity, uniformity, mechanisation and mathematical formulas now become the building blocks of such a reality and being human becomes absolutely quantifiable. Therefore it is disturbing when one identifies traces of Descartes' philosophy in the HGP, which eventually wants to make man the "lord and master" of creation. Human beings have to work out their own salvation and, with their knowledge and technology, death and pain are therefore eliminated as far as possible. In this way, medicine and medical technology obtain soteriological dimensions. Woody Allen said on one occasion: "I don't want to achieve immortality through my work. I want to achieve it by not dying." Lurking behind the HGP there may indeed be an understanding of reality as a utopia which can be created, and a human being who can become divine. Then there will no longer be room for God. 
This reification of reality occurs mainly because of the loss of reference in language. The classical Quadriga in hermeneutics is traded in and only the factual and literal meaning remains. The stylistic features of analogy, symbolism and metaphor vanish and people find themselves in a onedimensional world. Then reality no longer has any telos left. But one should surely also add that science is a people issue. After all, the reference does not lie in the matter itself, but in the reference to the person behind the instruments. After all, the HGP is not in itself reductionist. Reductionism is a particular understanding of reality. In particular, it was philosophers such as Michael Polanyi (1964:10) who point out to us that the natural sciences can never release us from our own presuppositions: "Every interpretation of nature, whether scientific, non-scientific or anti-scientific, is based on some intuitive conception of the general nature of things."

It is clear that a larger frame of reference will eventually have to determine ethics. ${ }^{8}$ The case of Celera Genomics indicates that medical research often has a monetary thrust. Dr Graig J Venter and his team endeavoured at the time to be the first to map the human genome so that they could get it patented as intellectual property. The question of course is whether one should in any way dare to patent the human genome (see also Peters 1997:115-141; 2003:143-146). "How do you patent a person's hand?" someone once asked in this regard. The distinction between "discover" and "invent", and also between "living" and "lifeless" things, has to be observed in this case, as the Conference of European Churches (CEC) advised the European Parliament. Lifeless things can be patented, living things cannot. But in effect it still seems that, due to the financial benefits associated with a patent, turning human beings into commodities may well occur, entailing with it a reduction in our understanding of humankind.

Junker-Kenny and also Reed give particular recognition to Kant ([1948]1972:91) who did not regard man as a means to an end, but as an end in itself ${ }^{9}$ (Deane-Drummond 2003:125, 281). This is so because of a transcendental concept which places dignity as the potentiality (not the actuality) as central to morality.

What is relative to universal human inclinations and needs has a market price; what, even without presupposing a need, accords with a certain taste - that is, with satisfaction in the mere purposeless play of our mental powers' - has a fancy price ("Affektionspreis"); but that which constitutes the sole condition

\footnotetext{
${ }^{8}$ See in this regard the brilliant book by William Schweiker 2004. Theological ethics and global dynamics. Oxford: Blackwell.

9 "Act in such a way that you always treat humanity, whether in your own person or in the person of any other, never simply as a means, but always as the same as an end."
} 
under which anything can be an end in itself has not merely a relative value - that is, a price - but has an intrinsic value - that is, dignity.

(Kant [1948]1972:96)

It is inadequate, however, merely to refer to this when rejecting patenting or commodification. A better argument, theologically speaking, would be to point out that these would adversely affect the sacramental nature of human life. After all, this supersedes an absolute understanding of being human. A person's dignity is vested in his or her being part of the body of Christ. Ether Reed succeeds in understanding Christ as the interface between God and man, without doing violence to the ontological gulf discussed with reference to Kant (Deane-Drummond 2003:283). One could understand this as analogous to the koinonia at Holy Communion. The real presence of Christ at Holy Communion should be understood not as an atomist but as a congregational presence. Since the 11th century the corpus verum has unfortunately been exchanged for the corpus mysticum and the former has been understood as the congregation and the latter as Holy Communion. I Corinthians 11:24 apparently does not want to say that the elements are, in a mysterious or even worse in a mystic way, part of the body of Christ. Koinonia is the body of Christ and this fellowship is what Paul said the Corinthians had to see. Man's dignity is therefore vested in the sacramental community of saints. That is why a posteriori statements alone can never suffice for ethics, as ethics should also take a priori convictions into account. Being human is not merely a genomic matter, but a sacramental experience. This is also the root of society's Christian identity.

\section{SEARCH FOR A "SPECIES ETHICS"10}

When someone like Roger $\operatorname{Shin}{ }^{11}$ states that in principle there is no ethical difference between treating a symptom and a gene, it is clear that he really means there is no medical difference. Genetic manipulation is in other words comparable to inoculation. Once again this is a naturalistic view of man because it ignores that which essentially belongs to human identity. God, genetic manipulation and medical wellness are declared a seamless whole (Deane-Drummond 2003:306). This is indeed a blending of ontologies. The other matter associated with this, is that there is definitely no one-to-one

\footnotetext{
${ }^{10}$ Habermas, J 2003. The future of human nature. Cambridge: Polity Press.

${ }^{11}$ Shinn, R L 1998. Genetics, ethics and theology: the ecumenical discussion, in Peters, $T$ (ed), Genetics: issues of social justice. Cleveland: Pilgrim Press. 122-143.
} 
relationship between a gene and a particular character trait. Human beings can never be reduced to a mere collection of biological cells - which is a real danger the HGP holds (Deane-Drummond 2003:123, 302 inter alios). Moreover the diversity in human genes also has to be noted. In other words, polymorphism should not be "pathologised", but recognised (DeaneDrummond 2003:120). This would naturally also do justice to human freedom.

Only when the mentioned commensalism is complemented with active acts of justice, is Holy Communion not without content. Stated differently, it should be oriented to the world in order to address suffering. This leads to a sacramental ethics of technology. God's goodness is always altruistic and eccentric. It leads to doxological and practical reaction. Through this we understand human genes always as genes-in-community. ${ }^{12}$ The HGP must make us change our metaphors: from abstract maps to physical people. Wellness should furthermore not be understood individualistically, but precisely in terms of the community. In fact, Ruth Page's understanding of the image of God as also meaning all of creation, gives this imperative ecological contours.

This brings one to Deane-Drummond's understanding of the basic virtues, especially practical wisdom as the mother of all other virtues (but together with it also justice, courage and self-control) based on her reading of Aristotle and Aquinas, as a middle way in a casuistic and consequentialist or utilitarian ethics. ${ }^{13}$ She wants to link it to the faith, hope and charity in I Corinthians 13 (Deane-Drummond 2003:225). She also relies heavily on James Gustafson's ${ }^{14}$ classical work on ethics and does not merely want to have a priori points of departure, but a type of deontological ethics advocated from a holistic framework of Creator and creation. She thinks that the theory of virtue, complemented with this Biblical triad, may combine two matters without sacrificing the independence of either. Since it is not handled absolutely, it may allow room for natural scientists' personal prejudices. What would remain in common, however, is the telos. In this way a middle term is found between the Kantian deontology and a post-modern deconstructionism. Therefore she can define reality as "... both supernatural and natural". In the footsteps of

\footnotetext{
${ }^{12}$ This should naturally not be confused with what Richard Dawkins meant with his "meme" as pendant for genes: "Just as genes propagate themselves in the gene pool by leaping from body to body via sperm or eggs, so memes propagate themselves in the meme pool by leaping from brain to brain by a process which, in the broad sense of the term, can be called imitation." McGrath judges that not Darwin's, but Lamarck's undertanding of evolution opens up a cultural rather than a scientific dimension. Darwin's focus was on replicating genotype whereas Lamarck's was on the phenotype (McGrath 2005:122, 127).

${ }^{13}$ See also Bryant \& Searle (2004:23).

${ }^{14}$ Gustafson, J 1974. Theology and Christian Ethics. Cleveland: Pilgrims Press.
} 


\section{The Human Genome Project as a case study}

Aquinas, even the vestigia of God can be recognised in creation (DeaneDrummond 2004:74). This is also linked qualitatively to Kant's archetype. Now the deduction can be made that the book in question succeeds in recognising a correspondence between the higher ontological (causal) orders and the higher epistemological (explanatory) levels. Therefore ethics cannot be practised independently of theology. Ethics cannot be founded purely on reason, not even on practical reason. It requires a comprehensive tradition, which is understood as narrative and stories (Murphy \& Ellis 1996:107, 116). Now we may also say, within an ecclesiastic community (Hauerwas). Herein lies man's telos or meaning.

\section{APPRECIATION}

Even what is known as Einstein's two-languages theory (1984:18), engendering the possibility of combining non-autogenous matters where natural science asks the question "can" and theology asks the question "may", has its own problems. This theory is still about different voices from two different domains, so the consonance remains unsettled. The two different languages also have a different orientation: the one speaks to God and the other to the world. So it is also good that we read in the book under discussion that the option of indifference between theology and natural science is also acceptable (Deane-Drummond 2003:146). By this is understood that matters which should be combined are indeed separated. A priori and a posteriori matters cannot be separated like this, and creation and Creator cannot be identified with each other nor be absolutely separated from each other. This route is also pertinently taken in Brave new world? Ethics is therefore bound to science, but not reducible to it.

People often misunderstood Aquinas' "Five Ways". This is not a way of proving God's existence cosmologically but of speaking reasonably about God from the presupposition of faith (Allen 1985:145). My view is that this is how one should speak about nature. By implication it has already been said that nature is more a social-constructionist concept than an objective entity. Nature is invariably the product of a particular understanding of reality. How can we base a philosophy on nature if nature is already the result of our philosophical ideas? Any attempt to base a philosophy or a theology on nature therefore first has to place nature in a preceding ontology. This would also recognise matters which belong together as such. My assumption is therefore that the Biblical theory of creation should serve as a broad framework for dealing with nature and also for interpreting it. This would combine theology and nature. Jürgen Moltmann (1985:12) is closest to the mark with his Pneumatological theory of creation: "Diese Schöpfungslehre, die vom einwohnenden, göttlichen Schöpfungsgeist ausgeht, soll auch Ansatzpunkte für das Gespräch mit den 
alten und neuen nichtmechanistischen, sondern ganzheitlichen

Naturphilosophen bieten." T F Torrance as well as A E McGrath also have in common with Moltmann this epistemological Trinitarian foundation as a precondition for understanding reality. Therefore Torrance (e $\mathrm{g}$ in 2001:91) is also right when he understands revelation as the greater circle around nature. Let me use an example as explanation. Einstein (1984:42) believes that geometry forms the matrix for understanding physical reality:

Geometry, from a physical standpoint, is the totality of laws according to which rigid bodies mutually at rest can be placed with respect to each other (e.g., a triangle consists of three rods whose ends touch permanently). It is assumed that with such an interpretation the Euclidean laws are valid. "Space" in this interpretation is in principle an infinite rigid body (or skeleton) to which the position of all other bodies is related (body of reference).

Einstein's theory of relativity overturned Newtonian dualism between absolute mathematical time and space on the one hand, and bodies in motion on the other. Consequently, geometry is not independent of physics as if it were an isolated conceptual system, but is integrated with physics and becomes a kind of four-dimensional science in itself. Then it becomes an epistemological structure in the midst of physics and can never exist as such on its own. In the same way we can now understand revelation as the time-space structure of a natural theology (Torrance 1998:ix, 2001:93). Natural theology is never a praeambula fidei, but an integral part of theology. It becomes the matrix for interpreting all experience of God in creation. Therefore it also opposes Kant's separation of subject and object, where faith is robbed of any ontological reference and is consequently divested of any proper cognitive content.

Theology is therefore essentially an a posteriori science. It reacts to God's creation. When McGrath (2002:306), in his qualified identification with Schleiermacher, states that "Christ functions as both the foundation and criterion of an authentically Christian theology", this still comes close to the mentioned archetype in man. The incarnation illustrates this too. ${ }^{15}$ We should also take our understanding of Jesus (who is homoousios God) as point of departure in our theology, and not work with a priori points of departure as though we began everything ourselves. The question is therefore not whether the incarnation is possible, but because it is, theology has to be consistent with it (see Torrance 2001:108, 122). This is also what Luther meant by his theologia crucis. Heaven and earth came together there, and that is now our point of departure. We do not create God, we bear witness to Him. Stated differently, what our argument comes down to is that one's ontology

${ }^{15}$ This is in any event how John Macquarrie $(1980: 184,1998: 102)$ also interprets Kant in this. 
determines one's epistemology. ${ }^{16}$ This ontological integrity of creation is surely the exact meaning of $E=m c^{2}$ too.

Instead of a dualistic understanding of reality, we could rather see reality in its many layers (inter alios Murphy \& Ellis 1996:86). This would not allow us to disregard the classical analogia entis without further ado. In a derivative sense, it also has its place. The interface is there and one can speak about it in terms of différance (Derrida). Critical realism wants to give expression to precisely this (inter alios Van Huyssteen 1999:219). That is why theology is not only the "grammar" (Lindbeck) of creation, but also in fact its "ground and grammar" (Torrance). Through this the internal coherence of theology is complemented by an external foundation. Theology is therefore always the understanding of reality.

Nevertheless, the popular alternative of a monism (inter alios Cobb and though qualified, even Dingemans \& Smelik) should be consistently rejected. This kind of immanentism calls into question the merciful presence and freedom of God. It also calls into question the contingency of creation and could eventually even end up, as in Whitehead's case, in pantheism.

In this article, I wish to give positive recognition to Deane-Drummond, whose book does indeed make a positive contribution, within the abovementioned contours, to the debate between theology and natural sciences. Matters that belong together have not been separated and those that differ have been combined but solely metaphorically.

\section{Works consulted}

Aldhaus, P 2001. Can they rebuild us? Nature, vol 410, 5 April 2001. http://www.genetics-and-society.org/resources/items/20010405 nature aldhous.html

Allen, D 1985. Philosophy for understanding theology. Atlanta, GA: John Knox.

Barbour, I 2000. When science meets religion. New York: HarperCollins.

Barth, K 1970. Die Lehre von der Schöpfung. Die Kirchliche Dogmatik III/1. Zürich: EVZ.

Bryant, J \& Searle, J 2004. Life in our hands: A Christian perspective on genetics and cloning. Leicester: Inter-Varsity Press.

Buitendag, J 2005. Anders dink anders doen: Op soek na 'n eko-teologiese perspektief op kloning. Verbum et Ecclesia 25(2), 402-422.

Cobb, J B \& Griffen, D R 1979. Prozess-Theologie. Göttingen: Vandenhoeck \& Ruprecht.

Deane-Drummond, C (ed) 2003. Brave new world? Theology, ethics and the human genome. London: T\&T Clark.

Deane-Drummond, C E 2004. The ethics of nature. Oxford: Blackwell.

\footnotetext{
${ }^{16}$ Ted Peters (2005:2) sees the difference as more epistemological than ontological and distinguishes between a natural theology which begins with unbelief, whereas a theology of nature begins with belief. The latter interprets nature as God's creation. A theology of nature takes some hypotheses from nature in order to interpret and understand reality.
} 
Dingemans, G D J \& Smelik, P G 2005. Deze wereld en God. Kampen: Kok. Einstein, A 1984. Out of my later years. New York: Citadel Press.

Gustafson, J 1974. Theology and Christian Ethics. Cleveland: Pilgrims Press. Habermas, J 2003. The future of human nature. Cambridge: Polity Press.

Hefner, P 2002. Genetic frontiers: Challenges for humanity and our religious traditions, in Chicago Center for Religion and Science, Homepage. Accessed on 23/06/2004. http://www.zygoncenter.org/zygonside.html.

HGPI 2003. Press release, 14/04/2003. Bethesda. (http://www.ornl.gov).

Kant, I 1960. Religion within the limits of reason alone, $\operatorname{tr}$ by $\mathrm{T} \mathrm{M}$ Greene \& H H Hudson. New York: Harper \& Row.

Kant, I [1934]2000. Critique of pure reason. A revised and expanded translation based on Meiklejohn, edited by Vasilis Politis. London: Everyman.

Kant, I [1948]1972. The moral law: Kant's groundwork of the metaphysics of morals, ed by $\mathrm{H}$ J Paton. London: Hutchinson University Library.

Macquarrie, J 1980. Jesus Christ in modern thought. London: SCM Press.

Macquarrie, J 1998. Christology revisited. Harrisburg, PA: Trinity Press International.

McGrath, A E 2001. A scientific theology: Nature, vol I. London: T\&T Clark.

McGrath, A E 2002. A scientific theology: Reality, vol II. London: T\&T Clark.

McGrath, A 2004. The science of God. London: T \& T Clark.

McGrath, A 2005. Dawkins' God: Genes, memes and the meaning of life. Oxford: Blackwell.

Messer, N G 2001. The ethics of human cloning. Cambridge: Grove Books Limited.

Peters, T 1997. Playing God? Genetic determinism and human freedom. Routledge: New York.

Moltmann, J 1985. Gott in der Schöpfung: Ökologische Schöpfungslehere. München: Chr. Kaiser.

Muis, J 2005. Het kennen van God: In gesprek met Gerrit Immink. Kerk en Theologie 56(2), 97-112.

Murphy, N \& Ellis, G F R 1996. On the moral nature of the universe. Minneapolis, MN: Augsburg Press.

Newberg, A, D’Aquili, E \& Rause, V 2002. Why God won't go away: Brain science and the biology of belief. New York: Ballantine Books.

Peters, T 2003a. Science, theology and ethics. Aldershot: Ashgate.

Peters, T 2003b. Embryonic persons in the cloning and stem cell debates. Theology and Science 1(1), 51-77.

Peters, T 2005. Natural theology versus theology of nature, in Theology and Science $3(1), 1-2$.

Polanyi, M 1964. Science, faith and society. Chicago, IL: University of Chicago Press.

Schüklenk, U 2002. Ethics, politics and embryo stem cell research in South Africa. South African Medical Journal 92, 782-786.

Schweiker, W 2004. Theological ethics and global dynamics. Oxford: Blackwell.

Song, R 2002. Human genetics. London: Darton, Logmann \& Todd Ltd.

Taylor, J 1901. The rule and exercises of holy dying. London: J M Dent \& Co.

Torrance, T F 1998. Space, time and resurrection. Edinburgh: T\&T Clark.

Torrance, T F 2001. The ground and grammar of theology. Edinburgh: T\&T Clark.

Van Huyssteen, W 1999. The shaping of rationality. Grand Rapids, MI: Wm B Eerdmans. 